\title{
Work of gravediggers and health
}

\author{
Fernando Pinheiro $^{\mathrm{a}^{*}}$, Frida Marina Fischer ${ }^{\mathrm{a}}$ and Claudio José Cobianchi ${ }^{\mathrm{b}}$ \\ ${ }^{a}$ Department of Environmental Health, Faculty of Public Health of the University of São Paulo, 715 Dr. Arnaldo \\ Av, São Paulo, Brazil. \\ ${ }^{\mathfrak{b} D e p a r t m e n t ~ o f ~ P s y c h o l o g y, ~ C r u z e i r o ~ d o ~ S u l ~ U n i v e r s i t y, ~} 868$ Galvão Bueno St., São Paulo, Brazil.
}

\begin{abstract}
Gravediggers have death as object of their work. Their activities are painful, physically and mental demanding, as well as unhealthy. Literature is scarce about this theme. The aim of this study is to evaluate gravediggers' work activities and health consequences. The methodological frame which guided this study was Dejours' psychic suffering and its association with the psychodynamic aspects of work. Data collection took place in April-May 2011 in one public and one private cemetery of São Paulo, Brazil. Four male workers, aged between 45 to 60 years old were interviewed. Their work activities were observed during a workday. Participants reported their life dreams, defense mechanisms and frustration. The discourse of gravediggers showed serious problems associated to physical and mental demands, public invisibility and/ or social devaluation of work. The most important physical symptom was body pain. In spite this is a preliminary study, it was possible to raise a number of work stressors and health outcomes of gravediggers, an "invisible" worker of our society.
\end{abstract}

Keywords: gravediggers, work demands; ergonomics; occupational health

\section{Introduction}

Based on the review published by Albornoz (1994), the work can be bad, tortuous and tiring (labor). A large number of jobs show a trend in our contemporary society: reduced physical and increase in mental demands at work. However, some occupations still present high physical demands, while keeping also significant mental stressors. This is the case of the work performed by gravediggers. Their work is quite invisible to the general public, and often considered as unhealthy and repulsive as death. Maranhão (1985) called this phenomenon by pornography of death. The pornography that was a forbidden subject and could not be fully exposed until a few decades ago has become a topic accepted by society. However death, a natural phenomenon, has become nasty, with the administration of bodies being held by funeral services. This is a paradox that reinforces the prejudice of the professionals who deal directly with death.
Studies about work and health of gravediggers are still scarce reported in the scientific literature. The work activities can be also associated with musculoskeletal disorders. The closeness to death may expose workers to living organisms that could transmit infectious diseases and other illnesses, including mental suffering. Triassi et al (2003) analyzed the exposure of workers who deal directly with mortal remains. These materials may contain contaminants to which workers would be exposed during the preparation of bodies, burial and exhumation. Eng et al (1984) studied the exposure of workers from the funeral industry. And Davidson \& Benjamin (2006) focused the prevalence of the legionnaries' disease on gravediggers.

Statistics indicates that about 250 people die every day in the city of São Paulo' ${ }^{1}$. São Paulo has the total of 40 cemeteries, with 19 of those belonging to the public service and 21 being private cemeteries ${ }^{2}$. Around 1,400 gravediggers work on the public funeral service in São Paulo ${ }^{3}$. This information was not

*715 Dr. Arnaldo Av., São Paulo, Brazil. Phone: 55-(11)-3061-7115. E-mail: fernandogustavo.ps@hotmail.com.

${ }^{1}$ Extracted from http://oglobo.globo.com/sp/mat/2007/10/30/326951343.asp in September 1st, 2011

${ }^{2}$ Extracted from http://minhanoticia.ig.com.br/editoria/Meio_Ambiente/2010/05/24/cemiterios + de + sao + paulo + enfrentam + problemas + de + contaminacao+9489199.html in September $1^{\text {st }}, 2011$

${ }^{3}$ Extracted from http://agenciabrasil.ebc.com.br/noticia/2011-09-01/justica-determina-fim-da-greve-dos-coveiros-de-sao-paulo in September 1st, 2011 
found about the number of workers in private funeral services. The aim of this study is to report characteristics of the work performed by gravediggers and some of health outcomes.

\section{Method}

We've performed a search for references which include the PubMed and Scielo online databases.

Four in-depth semi-directed interviews (Severino, 2003) took place in one public and one private cemetery of the city of São Paulo, Brazil. These interviews were performed during working hours, from April to May in 2011. A comprehensive number of items were included in the interview, such as sociodemographic, living and working conditions, social relationships, life styles and health outcomes. Living conditions included affective aspects of the workers' relationships, family history; as for working conditions, questions were asked about their work activities and work stressors. Social relationships during leisure time, social roles and social identities were included. Life styles such as drinking and smoking habits were investigated. Health questions addressed illnesses, sleep, and other topics about general health (physical and mental aspects).

Working tasks of inhumations, exhumations and activities related to cemetery cleaning were observed. Body postures, use or absence of personal protective equipment and perception to exposure to dangerous and contaminant material were also included in the interview/observation.

\section{Results}

Work routines were different comparing public and private cemeteries. Along the observations, it was noted that work was more intense in the public cemetery, demanding greater physical demands of the workers. As for body postures and pain symptoms: workers reported that they feel pain, although in younger and those with less time in the profession, reports are that these are less frequent. The workers did not associate their health problems (body aches, respiratory problems by inhaling dust and solid waste including human remains,) to work activities. It was also reported irregularities in their work schedule and time-off, and reduction in sleep duration during working days. The four workers interviewed were living far from the cemeteries and woke up around
5:00 am. The work began around 07:30 am to 05:30 $\mathrm{pm}$. The sociodemographic data showed that these workers had a low educational status: one of them had four years of basic education, and the other three, up to 8 years. All four participants began working with ages between 14 and 17 years. Their monthly salary was approximately US $\$ 400.00$.

In the private cemetery workers wore protective equipment (mask, gloves, and boots). In the public cemetery, only one of the workers wore boots, and the other wore no mask. The interviewed gravediggers showed an early familiarity with work in cemeteries, been introduced to this kind of activity in early age working together with family members who have dealt formerly with these jobs. One of the participants reported that "I wanted to learn to work with marble, but found out that working in a cemetery has nothing to do with (working) marble".

Defense mechanisms were observed both in speech and behavior of workers during the work performed. It will be mentioned some of them: 1) Rationalization. An example is reported: "... today, I work and do not remember that this is a cemetery... it's like I am working elsewhere, a garden or a ranch.. " . Another example: “... a gravedigger is one who plants cabbages" (a pun in Portuguese). These two sentences express a desire to get away from him the idea to perform unpleasant tasks. 2) Denial. It could be observed as two of the workers did not want to wear individual protective equipment. They reported no harm could originate from their work. 3) Contradiction (or sense inversion). The workers try to conform to reality. Excerpts: "It does not help to demand", "the worker must accept and think is good", " we do not have to complain" and there is nothing to complain". 4) Projection. Workers reported about the unfulfilled dreams and goals that were left behind have been reported as an example of this defense mechanism. They wished their children's success, particularly male heirs, social recognition and better life. Excerpts: "My daughter is very beautiful but my son is very good in math... My son is studying Accounting and then will study Mathematics". My family does not like my job, and my children suffered prejudice when colleagues knew their father is a gravedigger". Another result deals with prejudice. Workers felt undervalued compared to other professions that also have (eventually) proximity to death, as is the case of doctors and nurses. Excerpts"... I got to a hospital as a relative of mine was admitted. The clerk asked me about my job. I replied saying I am a gravedigger; the nurses overheard the conversation and replied..." Are you are a gravedigger? Geez, chills me up!". They also 
ger? Geez, chills me up!”. They also reported that "...coroners and gravediggers, who make a job as important as doctors and nurses, are discriminated by the society that did not recognize their work as valuable". This last remark also relates with social invisibility.

\section{Discussion}

The results showed gravediggers face quite distinct stressors at work. They should cope with important mental demands, as their statements reported defense mechanisms. Applying the psychodynamic perspective presented by Dejours (1988) to the case of gravediggers, the psychic suffering emerges as a result of some of the working demands. Dejours mentioned the defense mechanism can be understood as an attempt to move away from ideas/facts that may cause suffering. In the case of the gravediggers, they try to deny the possibility to accept both their death, and hazards due to the work activity. Their frustration is presented as not having been able to work with something that would bring them valuable learning. Their discourses suggest a mechanism of rationalization, as they try to forget their reality relating this to rational and concrete explanations.

Besides the psychological demands, some other factors can influence drastically the health of workers. Life and familial history, premature frustration, economic needs and early school dropout were reported topics. Fischer et al (2003) mentioned that often poor adolescents tend to leave studies earlier either searching for economic stability, or looking for jobs to help the family. They left their "dreams and aims for later". Low education level lead to low pay jobs, as this is the case of the gravediggers.

Our society is conditioned to attribute qualities and deposit high pride labeling and recognizing the importance of some workers and to forget others. The social invisibility is responsible by a great variety of social illnesses (Celegium \& Roesler, 2009). These ones can reflect highly in all spheres of life of the worker - be it social or subjective. The consequences may be different because the worker does not receive emotional support and respect in your home tends to be discouraged from society.

The devaluation of their work originates in their own homes, and continues in the social environment. The elaboration of the meaning of death and mourning will bring a good or bad way to act against death, developing symptoms of denial or facing it healthily. (Kovács, 2008).

The workers commonly blame themselves by the occurrence of work injuries (Sato, 2006). This was also observed among the gravediggers. The gravediggers have difficulty to recognize that the work can lead to work injuries and problems related to the development of mental symptoms. They receive very little support from their employer and society, as prejudice and non-recognition mediates their relations with the outside world. Sato et al (2006) stated that in spite several companies are investing in mental support systems, still preventive practices are far from being applicable and adequate. This study presented a preliminary approach of the work of gravediggers. The observation and reported discourses showed that is prominent to establish health promotion programs and to disseminate among the public of the importance of the work performed by gravediggers. This would help to prevent work injuries, including mental illnesses, and a satisfactory work life.

\section{Acknowledgments}

Fernando Gustavo Pinheiro dos Santos receives a scholarship from CNPq/PIBIC.

\section{References}

[1] C. Dejours, A Loucura do Trabalho: Estudo de psicopatologia do trabalho, 3 ed., Cortez, São Paulo, Brazil, 1988.

[2] JLS. Maranhão, O que é Morte, Brasiliense, São Paulo, Brazil, 1985.

[3] RHK. Eng, M. Rothkopf and SM. Smith et al, Leggionaires' disease in a gravedigger: an epidemiologic study, New York State Journal of Medicine, New York, USA, 1984, 84, pp. 238-240

[4] CRJ. Celegium and H. Roesler, A Invisibilidade Social no âmbito do Trabalho, Revista Científica da Faculdade das Américas, São Paulo, Brazil, 2009, 3(1).

[5] MJ. Kovács, Desenvolvimento da Tanatologia: estudos sobre a morte e o morrer, Paidéia, São Paulo, Brazil, 2008, 18(41), pp. 468-478.

[6] L Sato, FAC Lacaz and MH Bernardo, Psicologia e saúde do trabalhador: práticas e investigações na Saúde Pública de São Paulo, Estudos Psicológicos, Natal, Brazil, 2006, 11(3), pp.281-288

[7] FM Fischer et al, Efeitos do trabalho sobre a saúde de adolescentes, Ciência e Saúde Coletiva, São Paulo, Brazil, 2003, 8(4), pp-. 973-984.

[8] AJ. Severino, Metodologia do trabalho científico, 23 ed., Cortez, São Paulo, Brazil, 2007.

[9] M. Triassi, S. Lopreiato, PV. Napoletano and S. Loria, Annali di Igiene, Italy, 2003 15(6), pp. 911-21. 
[10] SS. Davidson, WHJr. Benjamin, Risk of infection of workrelated infectious diseases in the funeral industry, American Journal of Infection Control, 2006, 34(10), pp. 655-660.

[11] W. Gomes, Paulistano tem vaga garantida no cemitério, O Globo Online, São Paulo, 08.30.2007, Plantão.

[12] EP. Cruz, Justiça determina fim da greve dos coveiros em São Paulo, Agência Brasil de Comunicação, 09.01.2011, Justiça.

[13] N. Reynaud, Cemitérios em São Paulo enfrentam problemas de Contaminação, iG Minha Notícia, 05.24.2011, Meio Ambiente. 